\title{
Factors Affecting the Productivity and Profitability of Vegetables Production in Swaziland
}

\author{
Bongiwe G. Xaba \\ P.O. Box C565, Manzini, M200, Swaziland \\ Micah B. Masuku (Corresponding Author) \\ Department of Agricultural Economics and Management, P. O. Luyengo \\ Luyengo. M205. University of Swaziland, Swaziland
}

Tel: 268-76-02-6557Ｅmail: mbmasuku@uniswa.sz

Received: May 24, 2013 Accepted: June 11, 2013

doi:10.5296/jas.v1i2.3748 URL: http://dx.doi.org/10.5296/jas.v1i2.3748

\begin{abstract}
Vegetables are not only beneficial for their contribution to the share of agriculture in the economy of Swaziland, but also have a significant probability to compete where there are fewer government regulations and restrictions in the economy. Currently, the local demand for vegetables is higher than local production and hence the gap is filled by imports from South Africa. At the NAMBoard's fresh produce market, only 11 percent of the vegetables are from local production and the rest come from South Africa. The study aimed to identify factors affecting productivity and profitability of vegetable production. A two-stage sampling technique was used to collect data from 100 vegetable farmers. Descriptive and inferential statistics were employed for data analysis. The results showed that the factors that significantly affected productivity of vegetable farmers were access to credit, selling price, fertiliser quantity, distance to market and gender of the farmer. For example, the selling price of carrot had a positive relationship with the productivity of vegetable farmers, suggesting that when the selling price of carrot increase by one unit, all else equal, the quantity of carrot produced would increase by 0.417 kilogrammes. The determinants of profitability of vegetable production were level of education, land under vegetable production and type of marketing agency. For example, with an additional year of education, profit would increase by E0.304. Policy makers should come up with policies that would improve productivity of vegetable farmers through the provision of seminars and workshops where farmers would acquire more training on vegetable
\end{abstract}


production. This should enable them to increase the average yield of vegetables produced per hectare, hence profitability.

Keywords: Vegetable productivity, Profitability, Vegetable production

\section{Introduction}

Changes in agribusiness systems and improvements in the agricultural sector of developing countries like Swaziland provide opportunities for smallholder farmers to commercialize agriculture (McCullough et al., 2008). However, rapid population growth, ongoing economic meltdown and unfavourable impacts of climate change might be accountable for the possible failure of progress in the agriculture sector. Agriculture has contributed significantly to the development of Swaziland's economy by providing the necessary raw materials required by agro-based industries that form the major support of the manufacturing sector. In 2011, agriculture contributed $11.9 \%$ to the country's GDP, while the agricultural activities practiced on Swazi Nation Land (SNL) contributed approximately 5\% of the country's GDP (Thompson, 2011). Agriculture also act as a source of income and food security to a large proportion of the rural households, a market for industrial products and an earner of foreign exchange. About $75 \%$ of the population obtains their living from agriculture, of which $60 \%$ of this household income comes from crops and livestock, while the remaining $15 \%$ is derived from wages and remittances and informal sector activities. The different agricultural activities that are practiced in the country include sugarcane production, citrus fruits, vegetable crops, maize and other cereal crops, cotton, forestry and livestock production (Thompson, 2007).

Vegetables are leafy green, stem, and root or even flower stalk portions of an edible plant. They are divided into conventional and baby vegetables. They are the same as conventional vegetables, but the difference is that they are much smaller in size. They are produced by growing genetically dwarf varieties or by harvesting the product before attaining full maturity. They supply vital nutritional materials as conventional vegetables and offer a more tender and delicate flavour to food (Braun \& Dlamini, 1994). Vegetables are effective in preventing micronutrient deficiencies and in the prevention of diseases. They create opportunities for smallholder farmers and are a source of a better life and income as well as significant for improving the feeding behavior for the people of Swaziland (Braun \& Dlamini, 1994).

Vegetable production in Swaziland is seasonal and farmers, especially on SNL produce maize in summer and vegetables in winter with the most commonly produced vegetables in the country being tomato, cabbage, carrot and onion. These could be labeled as the 'big four' and others include beetroot, lettuce, potato, green pepper, cauliflower, brussels sprouts and broccoli. Vegetables such as tomatoes, cabbages, carrots and onions can be grown in any part of the country and as a result, all vegetable growers usually produce these crops. From mid-winter to early summer these vegetables are usually plenty at the market place. The bulk of locally produced vegetables are sold within the country, but they can be sold outside the country if produced throughout the year and in significant quantities (NAMBoard, 2009).

The consumption of tomato, cabbage and onion has high income elasticity of demand, while the demand for carrot is almost inelastic (Mavimbela et al., 2010). Fresh vegetable 
consumption in the country is estimated around 40,000 tonnes per annum. This would translate into an annual per capita consumption of $40 \mathrm{~kg}$. High income households consume well above the national calculated average, while the majority of rural population and large proportion of the lower income households among the urban population consume very few vegetables (FAO/WFP, 2002). The purpose of the study was to investigate the productivity and profitability of vegetables production by smallholder farmers. Specifically the study sought to identify factors affecting the productivity of vegetable farmers and determinants of profitability of vegetables production.

\section{Literature Review}

\subsection{Vegetable Production and Marketing in Swaziland}

Swaziland produces different types of vegetable crops in the various agro-ecological regions as a source of income and for food security. Table 1 shows the vegetable crop status of the most commonly produced vegetables in Swaziland between the years 2005 to 2009. During the period 2005 to 2009 , a total of 559 farmers were involved in the production of cabbages, tomatoes, carrots and onions under a total area of 353.7 hectares. The total contribution of the vegetables to gross domestic product was E278, 481 by 2009.

Table 1. Status for the most commonly produced vegetables in Swaziland between the period $2005-2009$

\begin{tabular}{|l|l|l|l|l|l|}
\hline Vegetable Crop & Hectares & Number of farmers & $\begin{array}{l}\text { Average } \\
\text { returns/ ha }\end{array}$ & Cost of Production (E)* & $\begin{array}{c}\text { Contribution } \\
\text { to GDP }\end{array}$ \\
\hline Cabbage & 154.8 & 310 & 83,332 & 18,481 & 64,852 \\
\hline Tomatoes & 72.5 & 145 & 105,000 & 22,602 & 82,398 \\
\hline Carrots & 96.8 & 37 & 105,000 & 15,170 & 89,829 \\
\hline Onions & 30.4 & 61 & 62,500 & 21,097 & 41,402 \\
\hline TOTAL & 353.7 & 559 & 355832 & 77350 & 278481 \\
\hline
\end{tabular}

Source: NAMBoard, (2009).

*1US\$ equals E9.8 (April 2013)

For the past 15 years, the Government of Swaziland has been encouraging farmers to embark in baby vegetable production through the National Agricultural Marketing Board (Thompson, 2007). This has been one of the efforts by government to encourage farmers to diversify crop production activities on their farms. Farmers have willingly taken up the practice of baby vegetables production as they are currently 120 registered baby vegetable farmers in the country who are mostly located in the rural areas and cultivating on Swazi Nation Land (NAMBoard, 2009). The consumption of vegetables in Swaziland has been increasing over the years and the country is blessed with fertile soils which favour vegetable production (Sithole \& Grenoble, 2010). Climate is important for crop production. The climatic conditions in Swaziland are favourable to produce a wide range of vegetables and water for irrigation is enough, though additional developments are still necessary (Sithole \& Grenoble, 2010).

Marketing is fundamental for the success of vegetable farmers and therefore, farmers rely on good infrastructure, appropriate transportation facilities, improved technology and communication links to effectively market their products. Market participation becomes more 
profitable if farmers are able to minimize transaction costs and produce goods or services at a lower opportunity cost (Porter, 1985). Farmers can sell their vegetables through different marketing channels ranging from the farm gate, restaurants, wholesalers and supermarkets. The choice of an outlet may depend among other things on the agro-ecological location of the channels and whether the farmer is able to meet market requirements such as quality, safety standards and consistent supply.

Swaziland as a developing country requires an improved marketing system since the demand for vegetables is increasing very fast due to the growth in urban populations, opportunities to earn foreign exchange by exporting high value-off-season produce, offering better prices for products to small farmers and the contribution to employment made by its labour intensive production (FAO, 1986). Swaziland has a wide range of marketing systems including farmer markets, cooperative markets, contract markets and corporate markets. The interests of smallscale farmers are protected through farmer markets and cooperative markets, while the contract and corporate markets mostly cater for the commercial farms. The traditional markets found in most towns receive vegetables from local vendors who buy at the farm gate and deliver to the markets, however they choose to buy from bigger and more trustworthy farmers in South Africa due to the unevenly distributed areas of production and the unreliable of local supply produce (NAMBoard, 2009).

Makhura (2001) explored the transaction costs barriers in market participation of smallholder farmers in the Northern Province and he discovered that physical facilities, proximity to market, shortage of resources such as transport as well as shallow market information as the main limitations to farmer's marketing activities. The inability of farmers to bargain for prices together with limited credit relationships with the buyers led to farmers being exploited during the transaction where most of them end up accepting any given price. Most of the smallholder farmers in Swaziland encounter high production and transaction costs resulting to them not being able to sustain their livelihood (Hettige \& Senanayake, 1992; Kodithuwakku, 2000). Less developed rural economies and smallholder farmers find it difficult to participate in commercial formal markets due to factors such as shortage of nearby markets to absorb their produce, low produce prices, a lot of middlemen, unavailability of marketing institutions to facilitate contract enforcement and coordination among farmers (Emana \& Gebremedhin, 2007).

\subsection{Factors Affecting Vegetable Productivity and Profitability}

Adebayo (2007) studied the factors determining rain-fed rice production in Adamawa state in Nigeria using production function analysis. The results showed that the size of the farm and amount of seed significantly affect the productivity of rain-fed rice. Also resource productivity analysis indicated that seed was over- used, while land and herbicide were underutilized. Minimizing the quantity of seed used and maximizing the size of land and amount of herbicide respectively could increase efficiency. Rios et al (2008) also conducted an analysis on the direction of causality between market participation and productivity on multi-county farm households. The results indicated that regardless of market access factors, households with high productivity tend to participate in agricultural markets. In contrast being accessible to 
better markets does not actually lead to productivity. The finding implies that investment in markets access and infrastructure provides less advancement in agricultural productivity, whereas programmes targeted on enhancements in farm structure and capital have the potential to increase both productivity and market participation.

Likewise, Bezabih and Hadera (2007) examined the utilisation of low level agricultural technologies, risks related to natural occurances such as storms and disease outbreak to be the major sources of the decline in productivity. Furthermore, rapid population growth, the size of land allocated to each household has reduced resulting to a decrease in production. As a result farmers are adopting intensive production as a means of promoting agro- enterprise development in order to maximize land productivity. Vegetable production provides an opportunity for intensive production and increases smallholder farmer's participation in the market. Bezabih and Hadera (2007) further identified pest, drought, shortage of fertiliser, and price of fuel for pumping water as the major obstacles of vegetable production in Eastern Ethiopia. They also reported that insufficient knowledge in product sorting, grading, packing, and traditional transportation affect the quality of produce taken to the market.

Ahmed et al. (2003) applied a Cobb Douglas production function to quantify the contribution of various factors in muskmelon production. They discovered that variables such as family size, use of fertiliser and interaction of variety with pesticide sprays were highly significant towards muskmelon productivity. Ahmed et al. (2003) also quantified the contribution of various factors in tinda gourd production using the quadratic production function. The results showed that the amount of seed, fertiliser and the frequency of irrigation were significantly contributing in productivity to a certain level as the coefficient in squared terms was negative. This indicated that using the mentioned inputs above a certain level could have a negative effect on productivity. In a research carried out on the Fiji Sugar Industry by Reddy (1998), it was concluded that reducing input use save costs, but reduce productivity. Reddy (1998) found that land quality, labour, fertiliser, herbicides and machinery influence productivity. According to Reddy (1998), if land is turned into mortgageable, transferable commodity, farmers can use it as security to obtain loans required for productivity thus enhancing investments. This is only when the farmer has a title to the land. Labour shortages can also result in very high costs especially at harvesting time.

\section{Methodology}

\subsection{Research Design}

A descriptive cross-sectional research design was employed in the study with an aim of describing the productivity and profitability of vegetables farming in Swaziland.

\subsection{Sampling Procedure}

The sample frame of the study was a list of farmers engaged in the production of vegetables in Swaziland. In order to control frame and selection errors, an up-to date list of vegetables farmers was sought from the Ministry of Agriculture and NAMBoard's extension officers. A two stage sampling technique involving purposive and stratified random sampling was used to draw a sample of 100 farmers using the Van Dalen (1979) method of determining sample size. 
Conventional vegetables (cabbage, carrot, onion, tomato) and baby vegetables (baby corn and baby marrow) were studied. These crops accounted for the major proportion of vegetables produced in the country and they were in constant supply in the market (Lwazi Mhlongo. Personal communication, 22 September 2011).

\subsection{Data Collection}

A structured questionnaire consisting of both open and closed-ended questions was administered to sampled vegetable farmers through the use of face to face personal interviews. The questionnaire was reviewed by experts in the Department of Agricultural Economics and Management to establish content and face validity. Questionnaires were further pretested using farmers who were not part of the sample and a final questionnaire was prepared using responses obtained from the farmers.

\subsection{Data Analysis}

The study used both descriptive statistics and econometric model in analyzing data. Descriptive statistics included means, percentages, standard deviation and frequencies. A multiple linear regression model was employed to analyse factors affecting productivity and profitability.

\subsection{Analytical Framework and Empirical Models}

\subsubsection{Factors Affecting Productivity of Vegetable Farmers}

The determinants of productivity of vegetables were evaluated using multiple regression analysis. The model used was explicitly expressed as;

$$
\mathrm{Yi}=\beta_{0}+\beta_{1} \mathrm{X}_{1}+\beta_{2} \mathrm{X}_{2}+\beta_{3} \mathrm{X}_{3}+\beta_{4} \mathrm{X}_{4}+\beta_{5} \mathrm{X}_{5}+\beta_{6} \mathrm{X}_{6}+\beta_{7} \mathrm{X}_{7}+\beta_{8} \mathrm{X}_{8}+\beta_{9} \mathrm{X}_{9}+\beta_{10} \mathrm{X}_{10}+\beta_{11} \mathrm{X}_{11}+\mathrm{e}_{\mathrm{i}}
$$

Where:

$\mathrm{Y}_{\mathrm{i}}$ represents the average yield per hectare of vegetables produced

$\beta_{0}=$ constant

$\beta_{\mathrm{i}=}$ estimated coefficients of the explanatory variables

$\mathrm{X}_{\mathrm{i}}=$ explanatory variables

$\mathrm{e}_{\mathrm{i}}=$ disturbance term

The explanatory variables hypothesized to have a relationship with the dependent variable and their expected signs are presented in Table 1. The sex of the farmer was set as a dummy variable, where male took the value one or zero otherwise. No sign was expected a priori for this variable. The farmer's level of education was also set as a dummy variable taking the value one if the farmer was literate or zero otherwise. Education helps to unlock the natural talents and inherent enterprising qualities (Nwaru, 2004) of the farmers, thus making them more skilled and more responsive to risk taking and change than the illiterate farmers. Therefore, this variable was assumed to positively influence the productivity of vegetable farmers. The marketing agreement a farmer had with a marketing agency was measured by the availability of contractual agreements and this variable took the value one if there was an agreement, otherwise zero. The availability of contractual agreements ensures the availability of a 
guaranteed market for farmers, thus improving their productivity and profitability. This variable was expected to have a positive relationship with the dependent variable. Family labour reflected the availability of economically active labour in the household, either male or female. It was measured in man days. It was expected to have a positive sign indicating that an increase in economically active family labour would result to an increase in the productivity of vegetable farmers. Distance to market was measured by the kilometres from the area of production to the market. Closer markets reduce transportation costs, tracking time and loss due to spoilage, hence motivate the farmers to improve production. Therefore, it was hypothesised that distance to market would have a negative effect on productivity. The total land cultivated under vegetables was measured in hectares. It was expected to take a positive sign indicating that the more land cultivated under vegetables, the higher would be the productivity as a result of economies of scale.

Branson and Norvell (1983) discovered that expanding the land under crop production increased the volume of marketable produce. The quantity of each vegetable crop produced was hypothesized to have a positive effect on the productivity of vegetable farmers. Fertiliser quantity was measured in kilogrammes and was proposed to positively affect the productivity of vegetable farmers. It was assumed that the more fertiliser applied on vegetable crops up to a certain level, the more would be the quantity of vegetables produced. Access to credit was set as a dummy variable taking a value of one if the farmer had access to credit, otherwise zero.

Credit facilitates the introduction of innovative technologies and ensures input and output marketing arrangements (Reddy, 1998). It was also assumed to have a positive influence on the productivity of vegetable farmers because having access to credit services enable the farmers to purchase improved varieties and hence increase productivity at farm level. Higher prices for vegetables motivate farmers to ameliorate the quantity of the vegetables produced. It was expected that price increases would incentivise farmers to produce more vegetables, thus selling price was hypothesized to positively influence the productivity of vegetable farmers Access to extension service was set as a dummy variable taking the value one if a farmer had access to extension services and zero otherwise. The purpose of the extension service is to introduce farmers to new and improved agricultural inputs and better methods of improving production and productivity and in turn increase marketable supply.

Table 1. Description of the independent variables used in productivity model

\begin{tabular}{|c|c|c|c|}
\hline Variables & Coding system & Category & $\begin{array}{l}\text { Expected } \\
\text { sign }\end{array}$ \\
\hline$X_{1}=$ Sex of the farmer & 1 if male, 0 if female & Dummy & $+/-$ \\
\hline$X_{2}=$ Education level of farmer & 1 if literate, 0 if illiterate & Dummy & + \\
\hline $\mathrm{X}_{3}=$ Marketing agreement & $\begin{array}{l}1 \text { if contracted, otherwise } \\
0\end{array}$ & Dummy & + \\
\hline $\mathrm{X}_{4}=$ Family labour & Man days & Continuous & + \\
\hline $\mathrm{X}_{5}=$ Distance to market & Number of kilometres & Continuous & + \\
\hline $\begin{array}{r}\mathrm{X}_{6}=\text { Total land cultivated } \\
\text { under vegetables }\end{array}$ & Number of hectares & Continuous & + \\
\hline $\begin{array}{c}\mathrm{X}_{7}=\begin{array}{c}\text { Quantity of each vegetable crop } \\
\text { produced }\end{array} \\
\end{array}$ & Number of kilogrammes & Continuous & + \\
\hline $\mathrm{X}_{8}=$ Fertiliser quantity & Number of kilogrammes & Continuous & + \\
\hline
\end{tabular}




\begin{tabular}{|c|c|c|c|}
\hline $\mathrm{X}_{9}=$ Access to credit by farmer & 1 if access, otherwise 0 & Dummy & + \\
\hline $\begin{array}{c}\mathrm{X}_{10}=\text { Price for each vegetable } \\
\text { Crop }\end{array}$ & Emalangeni/kg & Continuous & + \\
\hline $\begin{array}{c}\mathrm{X}_{11}=\text { Access to extension } \\
\text { Service }\end{array}$ & 1 if access, otherwise 0 & Dummy & + \\
\hline
\end{tabular}

\subsubsection{Determinants of Profitability of Vegetable Farmers}

Evaluation of the determinants of the profitability of vegetable farmers was conducted using multiple regression analysis. Gross margin per hectare was used as a proxy for profitability. The model was specified as:

$$
Y_{i}=\beta_{0}+\beta_{1} X_{1}+\beta_{2} X_{2}+\beta_{3} X_{3}+\beta_{4} X_{4}+\beta_{5} X_{5}+\beta_{6} X_{6}+\beta_{7} X_{7}+\beta_{8} X_{8}+\beta_{9} X_{9}+\beta_{10} X_{10}+\beta_{11} X_{11}+e_{i}
$$

Where:

$\mathrm{Y}_{\mathrm{i}}=$ is profitability of vegetable production, measured by gross margins per hectare

$\beta_{0}=$ constant

$\beta_{\mathrm{i}}=$ estimated coefficients of the explanatory variables

$\mathrm{X}_{\mathrm{i}=}$ explanatory variables

$\mathrm{e}_{\mathrm{i}}=$ disturbance term

The description of the explanatory variables and their expected relationships with the dependent variable are presented in Table 2.

Table 2. Description of the independent variables used in the profitability model

\begin{tabular}{|c|c|c|c|}
\hline Variables & Coding system & Category & Expected sign \\
\hline $\mathrm{X}_{1}=$ Age of the farmer & Number of years & Continuous & - \\
\hline $\mathrm{X}_{2}=$ Sex of the farmer & 1 if male, 0 if female & Dummy & $-/+$ \\
\hline $\mathrm{X}_{3}=$ Education level of farmer & 1 if literate, 0 if illiterate & Dummy & + \\
\hline $\mathrm{X}_{4}=$ Experience & Number of years in farming & Continuous & + \\
\hline $\begin{array}{r}\mathrm{X}_{5}=\text { Total land cultivated } \\
\text { under vegetables }\end{array}$ & Number of hectares & Continuous & + \\
\hline $\begin{array}{r}\mathrm{X}_{6}=\text { Access to market } \\
\text { information }\end{array}$ & 1 if access, otherwise 0 & Dummy & + \\
\hline $\begin{array}{c}\mathrm{X} 7=\text { Access to extension } \\
\text { services }\end{array}$ & 1 if access, otherwise 0 & Dummy & + \\
\hline $\mathrm{X}_{8}=$ Access to credit & 1 if access, otherwise 0 & Dummy & + \\
\hline $\mathrm{X}_{9}=$ Distance to market & Number of kilometres & Continuous & + \\
\hline$X_{10}=$ Number of dependents & Number of family members & Continuous & + \\
\hline $\begin{array}{r}\mathrm{X}_{11}=\text { Marketing } \\
\text { agency }\end{array}$ & 1 if NAMBoard, 0 otherwise & Dummy & + \\
\hline
\end{tabular}

An increase in the farmer's age was expected to negatively affect the profitability of vegetables. Nwaru and Iwuji (2005) reported that entrepreneurship gradually becomes less as the age of the entrepreneur increases. This is because the innovativeness and optimism of the entrepreneur as well as his mental capacity to cope with the challenges of his business activities and his mental and physical abilities to do manual work decrease with age. Thus age was expected to be negatively associated with profitability. The sex of the farmer had no a priori expectations, 
whilst education was believed to be important as it enlightens farmers on how best to strategise and to adapt to better marketing conditions. Experience in vegetable farming was expected to have a positive influence on profitability. As farmers become more experienced in production and marketing of vegetables through their involvement, their probability to participate in economic transactions will be higher, thus becoming more profitable. The amount of land cultivated under vegetables was expected to be positively associated with profitability. The more land put under production, the higher would be the profitability of the crop because of possible economies of scale. Access to market information was set as a dummy variable, where a farmer having access to market information took the value one and no access to information took a value of zero. Access to information was assumed to positively influence profitability, and similarly, access to extension services was set as a dummy variable equal to one if a farmer had access to extension service, otherwise zero. The aim of the extension service is to introduce farmers to new and improved agricultural inputs in order to improve production and productivity in turn increase marketable supply which has a positive effect on profitability. Access to credit was set as a dummy variable taking the value of one if a farmer had access to credit and zero otherwise.

Access to credit enhances the financial capacity of the farmer to purchase the necessary inputs. Therefore, it was hypothesised that access to credit would have positive influence on profitability. The further away the production area is to the market, the lesser would be the probability to participate in commercial vegetable production, hence poor profits because of high transport costs. Therefore, it was expected that the variable would negatively affect profitability. Quality requirements and sustainable vegetable production necessitate the adoption of labour intensive production and harvesting practices (Wollni et. al, 2008). Therefore households with large family sizes may cultivate more land, mainly because of the use of family members, who provide cheap labour force. Hence, this variable was expected to have a positive relationship with profitability. Marketing channel used by the vegetable farmer was assigned the value one if the farmer sold vegetables to NAMBoard, otherwise zero. This variable was expected to have a positive influence on profitability.

\section{Results and Discussion}

\subsection{Characteristics of Respondents}

The socioeconomic characteristics of vegetable farmers are presented in Table 3 . The mean age for the farmers was 50 years with a standard deviation of 15 years. The distribution of the farmers by gender revealed that there were a larger proportion of males (80\%) than females (20 13\%). In this study, the level of education was included to ascertain the respondent's ability to use and interpret agricultural information. People with high education level are likely to analyse and interpret information than those who have less education or no education at all (Marther \&Adelzadeh, 1998). The results showed that $4 \%$ of the respondents had no formal education at all, whilst $96 \%$ had formal education for those who attended school, $25 \%$ had gone up to primary level, whilst $54 \%$ had attained secondary education and $16 \%$ had tertiary education. The mean number of dependants for the respondents was 7 people. Both household size and number of dependants had an influence on production since they affect consumption 
and production (Randela, 2005). A large household size discourages selling of produce because the farmer has to supply household consumption needs before selling. Distribution of sampled farmers according to years of experience in vegetable production revealed that on average, the farmers had 14 years of experience. Table 3 groups the respondents according to total farm size and the mean value for farm size was 4.8 ha. The results show that only $10 \%$ of the vegetable farmers interviewed had title deed to the land they used and $90 \%$ of the farmers had the right to use the land they were farming on, through communal permission or lease. Ownership of land influences agriculture productivity, because farmers who do not own land can be reluctant to develop and maintain the land (Randela, et al. 2000). Furthermore, such farmers may have difficulty in obtaining loans for agricultural purposes because they cannot use the land as collateral since they do not have title deed for it. The results indicate that $60 \%$ of the respondents had farm income of less than E20,000 per annum.

Table 3. Demographic characteristics of sampled vegetable farmers

\begin{tabular}{|c|c|c|c|c|}
\hline Item & & & Number of Farmers $(\mathrm{N}=100)$ & Percent \\
\hline \multicolumn{5}{|c|}{ Age of Farmer } \\
\hline & $23-35$ & & 19 & 19 \\
\hline & $36-48$ & & 33 & 33 \\
\hline & $49-61$ & & 25 & 25 \\
\hline & $62-74$ & & 19 & 19 \\
\hline & $75-85$ & & 4 & 4 \\
\hline & Mean & 50 & & \\
\hline & $\mathrm{SD}$ & 15 & & \\
\hline \multicolumn{5}{|l|}{ Sex } \\
\hline & Male & & 80 & 80 \\
\hline & Female & & 20 & 20 \\
\hline \multicolumn{5}{|c|}{ Educational level } \\
\hline & Illiterate & & 4 & 4 \\
\hline & Literate & & 96 & 96 \\
\hline & Primary & & 25 & 25 \\
\hline & $\begin{array}{c}\text { Secondar } \\
y\end{array}$ & & 54 & 54 \\
\hline & Tertiary & & 16 & 16 \\
\hline \multicolumn{5}{|c|}{ Number of Dependants } \\
\hline & $0-4$ & & 31 & \\
\hline & $5-9$ & & 40 & 31 \\
\hline & $10-14$ & & 12 & 40 \\
\hline & $15-19$ & & 7 & 12 \\
\hline & Mean & 7 & & 7 \\
\hline & SD & 4 & & \\
\hline \multicolumn{5}{|c|}{$\begin{array}{c}\text { Land Tenure } \\
\text { Status }\end{array}$} \\
\hline & Title & and & 10 & 10 \\
\hline
\end{tabular}




\begin{tabular}{|c|c|c|c|c|}
\hline & \multicolumn{2}{|c|}{ Swazi Nation Land } & 90 & 90 \\
\hline \multicolumn{5}{|c|}{ Experience in Vegetable Growing (Yrs) } \\
\hline & $1-11$ & & 58 & 58 \\
\hline & $12-22$ & & 21 & 21 \\
\hline & $23-33$ & & 14 & 14 \\
\hline & $34-44$ & & 6 & 6 \\
\hline & Above 45 & & 1 & 1 \\
\hline & Mean & 14 & & \\
\hline & $\mathrm{SD}$ & 12 & & \\
\hline \multicolumn{5}{|c|}{ Total Land Owned (Ha) } \\
\hline & Below 1.0 & & 3 & 3 \\
\hline & $1.0-5.0$ & & 76 & 76 \\
\hline & $5.1-10.0$ & & 12 & 12 \\
\hline & $10.1-15.0$ & & 4 & 4 \\
\hline & $15.1-20.0$ & & 2 & 2 \\
\hline & $21.0-25.0$ & & 2 & 2 \\
\hline & Above 25.0 & & 1 & 1 \\
\hline & Mean & 4.8 & & \\
\hline & SD & 7.12 & & \\
\hline \multicolumn{5}{|c|}{ Farm Household Income (E) } \\
\hline & Below 5000 & & 31 & 31 \\
\hline & $5500-20000$ & & 31 & 31 \\
\hline & $20500-35000$ & & 13 & 13 \\
\hline & $35500-50000$ & & 8 & 8 \\
\hline & $50500-65000$ & & 2 & 2 \\
\hline Mean & & 6070 & & \\
\hline SD & & 2.117 & & \\
\hline
\end{tabular}

\subsection{Factors Affecting the Productivity of Vegetable Farming}

Multiple linear regression was employed to investigate factors affecting the quantity of vegetables produced per hectare. The analysis was undertaken for cabbage, carrot, onion, tomato, baby corn and baby marrow respectively. Respondents in the study revealed that not all vegetables produced were marketed. They pointed out that some vegetables were spoiled due to lack of markets. The results in Table 4 revealed only one independent variable (access to credit) that affects the productivity of vegetable farmers with respect to cabbage production. It was hypothesised that access to credit would enhance the financial capacity of the farmer to purchase the necessary inputs which have a positive effect on the quantity of cabbage produced. Credit also increases farm efficiency by enhancing the farmers' decision-making regarding to production. The coefficient of access to credit was significant $(\mathrm{p}<0.05)$ and positively related to the quantity of cabbage produced. The results suggest that when access to credit increased by one unit, all else equal, the quantity of cabbage produced would increase by 0.231 kilogrammes per ha. The increase in the quantity of cabbages produced per hectare would mean that the 
volume supplied to the market would also increase. The adjusted $\mathrm{R}^{2}$ indicates that about $17 \%$ of the variation in quantity of cabbage produced per ha was attributed to access to credit. $16 \mathrm{As}$ observed from the results in, the quantity of carrots produced was significantly $(\mathrm{p}<0.01)$ influenced by the selling price of carrot, and quantity of fertiliser and, gender of the farmer. The results indicate that when the selling price of carrot at the market and that of fertiliser are increased by one lilangeni, and when the respondent is male other than woman, the quantity of carrot would increase by $0.417 \mathrm{~kg}$ per ha, $0.344 \mathrm{~kg}$ per ha respectively. Males would have $0.180 \mathrm{~kg}$ per ha above that of women. The results further indicate that the quantity of onion produced is significantly $(\mathrm{p}<0.01)$ influenced by the quantity of fertiliser applied. An increase in the amount of fertiliser applied by $1 \mathrm{~kg}$ results in $0.634 \mathrm{~kg}$ increase in onion per ha. The quantity of tomato produced is influenced by the amount of fertiliser $(p<0.01)$ applied and the market selling price $(\mathrm{p}<0.05)$. An increase in the amount of fertiliser applied by $1 \mathrm{~kg}$ is associated with $0.477 \mathrm{~kg}$ increase on tomatoes produced, while an increase in price by E1.00 results in $0.22 \mathrm{~kg}$ in tomato produced.

Table 4. Determinants of productivity of vegetable farmers

\begin{tabular}{|l|l|l|l|l|l|}
\hline Variables & $\mathrm{B}$ & Std error & $\mathrm{t}$-value & $\mathrm{R}^{2}$ & Adjusted $\mathrm{R}^{2}$ \\
\hline Cabbage & & & & & \\
\hline Constant & 177279 & 58988.5 & 3.005 & & \\
\hline Access to credit & $.231^{*}$ & 31046.6 & 2.35 & .181 & .173 \\
\hline Carrot & & & & & \\
\hline Constant & -4876.2 & 2448.01 & -1.992 & & \\
\hline Selling price & $.417^{* *}$ & 402.409 & 5.008 & & \\
\hline Fertiliser quantity & $.344^{* *}$ & 16.761 & 4.195 & & \\
\hline Gender & $.180^{*}$ & 1934.89 & 2.27 & .438 & .42 \\
\hline Onion & & & & & \\
\hline Constant & 615.927 & 2076.29 & 0.297 & & \\
\hline Fertiliser quantity & $.634^{* *}$ & 32.94 & 8.107 & .401 & .395 \\
\hline Tomato & & & & & \\
\hline Constant & -99.811 & 2095.66 & 1.078 & & \\
\hline Fertiliser quantity & $.477^{*}$ & 6.344 & 5.344 & & \\
\hline Selling price & $.222^{*}$ & 608.094 & 2.487 & .368 & .355 \\
\hline Baby corn & & & & & \\
\hline Constant & -359.12 & 105.472 & -3.405 & & \\
\hline Fertiliser quantity & $.807^{* *}$ & 1.228 & 15.613 & & \\
\hline Distance to market & $-.201 * *$ & 0.854 & -3.906 & & \\
\hline Gender & $.155^{* *}$ & 78.949 & 3.044 & .754 & .746 \\
\hline Baby marrow & & & & & \\
\hline Constant & -22.479 & 172.033 & -0.131 & & \\
\hline Selling price & $.724^{* *}$ & 45.121 & 10.393 & .524 & .519 \\
\hline
\end{tabular}

** and * show the values that are statistically significant at 1 percent and 5 percent significant levels, respectively. 


\section{Macrothink}

The quantity of baby corn produced is influenced $(\mathrm{p}<.05)$ by fertiliser quantity, distance to market and the gender of the vegetable farmer. The coefficient of fertiliser quantity was 0.807 implying that when the quantity of fertiliser applied to baby corn is increased by $1 \mathrm{~kg}$, the quantity of baby corn produced would increase by $0.807 \mathrm{~kg}$ per ha, while a reduction in the distance, to the market by $1 \mathrm{~km}$ would increase the amount of produce produced and sold in the market. Hence the lower would be the transportation charges, reduced tracking time, reduced loss due to spoilage and better access to market information and facilities.

The transaction costs would be reduced if the market is located closer to the farmers. The sex of the vegetable farmer was also significant $(\mathrm{p}<0.01)$ and positively related to the dependent variable. The results suggest that the quantity of baby corn produced would be $0.155 \mathrm{~kg}$ for males more than that of females. The adjusted $\mathrm{R}^{2}$ suggests that $75 \%$ of the variation in quantity of baby corn produced was attributed to the variables in the model. The results further showed that the quantity of baby marrow is affected by selling price $(\mathrm{p}<0.01)$ The results imply that when the selling price of baby marrow at the market increased by one unit, the quantity of baby marrow produced would increase by $0.724 \mathrm{~kg}$ per ha. The adjusted $\mathrm{R}^{2}$ was 0.519 , hence $52 \%$ of the variation in quantity of baby marrow produced was attributed to the price variation.

\subsection{Determinants of Vegetable Profitability}

Multiple linear regression was used to identify determinants of profitability of vegetables. Gross margins per hectare were used as a proxy for profitability as it measures relative profitability. Table 5 indicates that the independent variables used in the model accounted for about $13 \%$ of the variation in profitability. The level of education had a positive relationship with profitability and was significant at $1 \%$ significance level. The results indicate that with an additional year of education, profitability would increase by 0.304 . Education helps unlock the natural talents of the vegetable farmers and inherent enterprising qualities (Nwaru, 2004). The coefficient for land under vegetable production and marketing agency significantly $(\mathrm{p}<0.05)$ influence profitability. The results suggest that an increase in land under vegetable production would result in a E0.22 increase in profitability, while farmers selling to NAMBoard had E0.190 less than those selling to other markets. The results further indicate that the type of marketing agency was significant $(\mathrm{p}<0.05)$ and negatively related to profitability. The coefficient was -0.190 suggesting that as farmers sold vegetables to NAMBoard, profitability decreased by 0.190 . This could be due to the lower prices offered by NAMBoard to the farmers.

Table 5. Determinants of vegetable profitability

\begin{tabular}{|c|c|c|}
\hline Variables & $\mathrm{B}$ & $\mathrm{t}-\mathrm{value}$ \\
\hline Constant & -231134.132 & -2.310 \\
\hline Age & -.031 & -.320 \\
\hline Experience & -.081 & -.840 \\
\hline Level of Education & $.304^{* *}$ & 3.203 \\
\hline Sex of the farmer & .062 & .648 \\
\hline Access to credit & -.192 & -1.371 \\
\hline Access to extension service & -.151 & -1.555 \\
\hline
\end{tabular}




\begin{tabular}{|c|c|c|}
\hline Access to market information & .070 & .728 \\
\hline Land Under Vegetables & $.215^{*}$ & 2.269 \\
\hline Number of dependants & .080 & .842 \\
\hline Distance to market & .088 & .811 \\
\hline Marketing agency (1 = NAMBoard, 0 otherwise) & $-.190^{*}$ & -2.021 \\
\hline $\mathrm{R}^{2}$ & .155 & \\
\hline $\mathrm{R}^{2}$ adjusted & .129 & \\
\hline
\end{tabular}

** and $*$ show the values that are statistically significant at $1 \%$ and $5 \%$ significance levels respectively.

\section{Conclusion and Recommendations}

This study examined the factors affecting the productivity and profitability of vegetable production. The study showed that access to credit, selling price, fertiliser quantity and gender were significant and positively related to the productivity of the vegetable farmers while distance to market was negatively related to productivity. Profitability of vegetables was influenced by farmers' level of education and land under vegetable production, while selling to NAMBoard negatively affected profitability.

Therefore, there is a need to improve the pricing system of vegetables. Farmers should form a production clusters to improve their market intelligence. This could be achieved through the formation of producer groups or cooperatives. In each group there should be an advisory committee trained in various aspects of marketing which will be able to have access to up-dated pricing information and make it available to farmers on time. Policies should be developed to enhance productivity of vegetable farmers through the provision of seminars and workshops where farmers would acquire more training on vegetable production. This would enable farmers to improve their productivity and hence profitability. Agriculture extension systems should be market driven, decentralised and farmer-led in order to improve vegetable productivity and profitability. Further research on the development of innovative extension systems within a changing global economy is therefore necessary.

\section{References}

Ahmed, M., Bezabih, E., Mohammad, J., \& Simeon, E. (2003). Analysis of Economic and Nutritional Impacts of Market-oriented Dairy Production in the Ethiopian Highlands. Socioeconomic and Policy Research Working Paper. Livestock Policy Analysis Program, International Livestock Research Institute (ILRI). Addis Ababa, Ethiopia.

Anonymous. (2002). Swaziland Special Report. FAO/WFP crop and food supply assessment mission to Swaziland. Mbabane, Swaziland.

Adebayo, E. F., \& Moses, J. (2007). Efficiency of Factors Determining Rainfed Rice Production in Ganye Local Government Area, Adamawa State. Journal of Sustainable Development in Agriculture \& Environment, 3, 20-30.

Altshul, H. (1998). Output to purpose review of DFID's Crop Post-harvest Programme, Value Addition to Agricultural Products. Natural Resources International Symposium, 53-61. 
Bezabih, E., \& Hadera, G. (2007). Constraints and opportunities of horticulture production and marketing in eastern Ethiopia. Dry Lands Coordination Group Report No 46. Grensen9b. Norway.

Branson, R., \& Norvell, D. G. (1983). Introduction to Agricultural Marketing. McGraw-Hill Inc, USA.

Braun, K. P., \& Dlamini, G. M. (1994). Swaziland. Plant Diversity and Conservation in Botanical Diversity in Southern Africa. Pp. 7-8. Proceeding of a conference on conservation of South Africa, Leipzig, Germany 6, 17-23.

Emana, B. \& Gebremedhin, H. (2007). Constraints and Opportunities of Horticultural Production and Marketing in Eastern Ethiopia. Dry lands Coordination Group Report No. 46.

FAO/WFP (2002). Swaziland Special Report. FAO/WFP crop and food supply assessment mission to Swaziland. Mbabane, Swaziland.

Hettige, S. T., \& Senanayake, S. M. P. (1992). Highland Vegetable Production and Marketing Systems. A report prepared for Agriculture Cooperative Development International/USAID.

Kodithuwakku, K. A. S. S. (2000). Analysis of Tomato Supply Chains in the Kandy district. An unpublished report prepared for University of Peradeniya.

Lyster, D. M. (1990). Agricultural marketing in KwaZulu: a farm-household perspective. Unpublished MSc Agric thesis, University of Natal, Pietermaritzburg.

Makhura, T. (2001). PhD dissertation on overcoming transaction costs barriers to market participation of smallholder farmers in the Northern Province of South Africa. University of Pretoria. June, 2001.

Marther, C., \& Adelzadeh, A. (1998). Macroeconomic strategies, agriculture and rural poverty in post-apartheid South Africa. http://www.info.gov.za/oth. Accessed 29/05/11.

Mavimbela, E. B., Grenoble, D. W., \& Mc Avoy, E. J. (2010). A Commercial Agricultural Production and Marketing Project Report. Mbabane, Swaziland.

McCullogh, E. B, Pingali, P. L., \& Stamolis, K. G. (2008). The transformation of agri-food systems: globalization, supply chains and smallholder farmers. FAO, Rome, Italy.

NAMBoard. (2009). Annual Report for National Agricultural Marketing Board, Manzini, Swaziland.

Nwaru, J. C. (2004). Rural Credit Markets and Resource Use in Arable Crop Production in Imo State of Nigeria. (Unpublished Doctorate Dissertation) Department of Agricultural Economics, Michael Okpara University of Agriculture, Umudike, Nigeria.

Nwaru, J. C., \& Iwuji, O. (2005). Marketing Margins and Their Determinants in Plantain Marketing in Owerri Agricultural Zone of Imo State, Nigeria. In A.M. Orheruata, S.O. Nwokoro, M.T. Ajayi, A.T. Adekunle, \& G.N. Asumugha, Agricultural Rebirth for Improved 
Production in Nigeria (eds.), In proceedings of the $39^{\text {th }}$ Annual Conference of the Agricultural Society of Nigeria, University of Benin, Benin City, Nigeria, 385-387.

Porter, M. E. (1985). Competitive Advantage. The Free Press, New York. Republic of Kenya. Kiambu District Development Plan 2002-2008. Ministry of Finance and Planning, Government printer, Nairobi.

Randela, R. (2005). Integration of emerging cotton farmers into the commercial agricultural economy. Unpublished $\mathrm{PhD}$ thesis, University of the Free State, Bloemfontein.

Randela, R., Liebenberg, C. F., Kirsten, J. F., \& Townsend, R. F. (2000). Demand for livestock tick control service in the Venda region, Northern Province. Agrekon, 39(4), 644-655. http://dx.doi.org/10.1080/03031853.2000.9523680

Reddy, M, V. (1998). Production and Economic Analysis of Fiji's Sugar Industry, Unplublished PhD Dissertation, Department of Agriculture and Resource Economics, Hawaii.

Rios, A. N., William, A, M., \& Gerald, E. S. (2008). Linkages between market participation and Productivity on multi-county farm households. Paper presented at an annual meeting, July 27-29, 2008, from American Agricultural Economics Association, Orlando, Florida.

Sithole, D., \& Grenoble, D. (2010). Status of production and marketing of vegetables in Swaziland and the role of national Agricultural Marketing Board. Mbabane, Swaziland.

Thompson, F. T. (2007). Swaziland Business Year Book. Christina Forsyth Thompson, Mbabane-Swaziland.

Thompson, F. T. (2011). Swaziland Business Year Book. Christina Forsyth Thompson, Mbabane-Swaziland.

Van Dalen, D. B. (1979). Understanding Educational Research. New York: Macgraw Hill.

Wollni, M., Lee, D. R., \& Thies, J. E. (2008). Effects of Participation in Organic Markets and Farmer-based Organizations on the Adoption of Soil Conservation Practices among Small-scale Farmers in Honduras. Paper presented at the American Agricultural Economics Association Annual Meeting, Orlando, FL, July 27-29, 2008.

\section{Copyright Disclaimer}

Copyright reserved by the author(s).

This article is an open-access article distributed under the terms and conditions of the Creative Commons Attribution license (http://creativecommons.org/licenses/by/3.0/). 